\title{
Streptococcus mutans-induced secondary caries adjacent to glass ionomer cement, composite resin and amalgam restorations in vitro
}

\author{
Cárie secundária adjacente a restaurações de \\ cimento de ionômero de vidro, resina composta \\ e amálgama induzida por Streptococcus mutans \\ in vitro
}

\author{
Adriana Gama-Teixeira(a) \\ Maria Regina Lorenzeti Simionato(b) \\ Silvia Nagib Elian ${ }^{(\mathrm{c})}$ \\ Maria Angela Pita Sobral(d) \\ Maria Aparecida Alves de \\ Cerqueira Luz ${ }^{(d)}$
}

(a) MSc; (d) PhDs - Department of Operative Dentistry, School of Dentistry, University of São Paulo.

(b) PhD, Department of Microbiology, Institute of Biomedical Sciences, University of São Paulo.

(c) $\mathrm{PhD}$, Department of Statistics, Institute of Mathematics and Statistics, University of São Paulo.

\begin{abstract}
The aim of this study was to define, in vitro, the potential to inhibit secondary caries of restorative materials currently used in dental practice. Standard cavities were prepared on the buccal and lingual surfaces of fifty extracted human third molars. The teeth were randomly divided into five groups, each one restored with one of the following materials: glass ionomer cement (GIC); amalgam; light-cured composite resin; ionreleasing composite; and light-cured, fluoride-containing composite resin. The teeth were thermocycled, sterilized with gamma irradiation, exposed to a cariogenic challenge using a bacterial system using Streptococcus mutans, and then prepared for microscopic observation. The following parameters were measured in each lesion formed: extension, depth, and caries inhibition area. The outer lesions developed showed an intact surface layer and had a rectangular shape. Wall lesions were not observed inside the cavities. After Analysis of Variance and Component of Variance Models Analysis, it was observed that the GIC group had the smallest lesions and the greatest number of caries inhibition areas. The lesions developed around Amalgam and Ariston pHc restorations had an intermediate size and the largest lesions were observed around Z-100 and Heliomolar restorations. It may be concluded that the restorative materials GIC, amalgam and ion-releasing composites may reduce secondary caries formation.

Descriptors: Dental caries; Streptococcus mutans; Dental materials.
\end{abstract}

Resumo: O objetivo deste estudo foi definir, in vitro, o potencial de materiais restauradores, usados rotineiramente na prática clínica, na inibição da cárie secundária. Cavidades padronizadas foram preparadas nas faces vestibulares e linguais de 50 terceiros molares humanos extraídos. Os dentes foram divididos aleatoriamente em 5 grupos, cada um restaurado com um dos seguintes materiais: cimento de ionômero de vidro (CIV); amálgama; resina composta fotopolimerizável; compósito que libera íons, e resina composta fotopolimerizável contendo flúor. Os dentes foram termociclados, esterilizados com radiação gama, expostos a um desafio cariogênico utilizando um sistema bacteriano com Streptococcus mutans e preparados para observação microscópica. Os parâmetros medidos em cada lesão formada foram: extensão, profundidade e área de inibição de cárie. As lesões externas formadas apresentaram camada superficial intacta e formato retangular. Não foram vistas lesões de parede no interior das cavidades. Após Análise de Variância e Análise de Componentes de Variância, foi observado que o grupo CIV apresentou as menores lesões e o maior número de áreas de inibição de cárie. As lesões formadas ao redor das restaurações de amálgama e Ariston pHc apresentaram tamanho intermediário e as maiores lesões foram observadas ao redor das restaurações dos grupos Z-100 e Heliomolar. Pode ser concluído que os materiais restauradores CIV, amálgama e compósitos que liberam íons podem reduzir a formação de cáries secundárias.

Descritores: Cáries dentárias; Streptococcus mutans; Materiais dentários. 


\section{Introduction}

Secondary caries has been considered a major reason for the replacement of restorations ${ }^{2,14}$. This fact has prompted the development of materials with the promise of having anticariogenic properties like the release of $\mathrm{OH}^{-}$, calcium and fluoride which are able to inhibit bacterial growth, decreasing both superficial colonization and acid production by microorganisms. Furthermore, fluoride can react with dental enamel, thus enabling remineralization. ${ }^{9}$

Materials with other ions with cariostatic properties can also reduce the development of caries through inhibition of bacterial activity. ${ }^{9}, 15$ Amalgam, for instance, contains some of these cariostatic agents, such as $\mathrm{Ag}, \mathrm{Cu}$, and $\mathrm{Zn}$ ions, which can be released by the restoration. Anticariogenic ion-releasing composites with biological principles have been produced, promising to have an anticariogenic behavior through the release of different ions, according to the specific oral conditions. ${ }^{19}$

Because of the large variety of restorative materials, some criteria should be established in order to support their choice regarding their anticariogenic potential. The aim of this study was to compare caries formation around different restorative materials, using an in vitro bacterial system to induce the development of lesions.

\section{Material and Methods}

Fifty extracted, non-erupted, human third molars without previous lesions or visible enamel defects were stored in distilled water at $4^{\circ} \mathrm{C}$. Approval by the Ethics Committee, Institute of Biomedical Sciences, University of São Paulo (ICB-USP, protocol 048/CEP) and by the Ethics Committee, School of Dentistry, University of São Paulo (FOUSP, protocol 10/00) was obtained.

Standard Class-V cavities, $4 \mathrm{~mm}$-long mesiodistally, $2 \mathrm{~mm}$-wide occluso-cervically and 2-mm deep, were prepared in the middle third of the buccal and lingual surfaces of each tooth, with a cylindrical plain cut diamond bur (n. 1090, KG Sorensen, Barueri, SP, Brazil) in a high speed air turbine handpiece under water spray.

The teeth were randomly divided into 5 groups ( $n=10)$, each one restored with one of the following materials on the buccal and lingual surfaces: group 1 - Glass Ionomer Cement - GIC (Ketac Fil Plus, ESPE, Medizin, Germany); group 2 - amalgam (Dispersalloy, Caulk Dentsply, Milford, DE, USA); group 3 - light-cured composite resin (Z-100, 3M, St. Pauls, MN, USA); group 4 - anticariogenic ionreleasing composite (Ariston $\mathrm{pHc}$, Vivadent, Schaan, Liechtenstein); group 5 - light-cured fluoride-containing composite resin (Heliomolar, Vivadent, Schaan, Liechtenstein). Following preparation, all cavities were cleaned with aqueous slurry of pumice and anionic detergent. The restorative techniques are summarized in Table 1.

The restored teeth were thermocycled at $5^{\circ} \mathrm{C}$ and $55^{\circ} \mathrm{C}$ distilled water baths for 700 cycles. Steel wires were attached to the roots of each tooth. The dental crowns were painted with 2 coats of acid-resistant nail varnish (Revlon, Oxford, NC, USA), except on the restorations, and on a 2 -mm wide border around them. The tooth/wire units were sterilized with gamma irradiation (25 kGy).

The development of carious lesions was induced in vitro with a bacterial system, following the method used by Dummer et al. ${ }^{3}$ (1982) and Gilmour et

Table 1 - Restorative techniques used.

\begin{tabular}{|c|c|c|c|c|c|}
\hline $\begin{array}{c}\text { Restorative } \\
\text { material }\end{array}$ & $\begin{array}{l}\text { Margin } \\
\text { finishing }\end{array}$ & $\begin{array}{c}\text { Phosphoric Acid } \\
(37 \%)^{b}\end{array}$ & Adhesive System ${ }^{b}$ & Cavity Fill & Polishing After $24 \mathrm{~h}$ \\
\hline GIC & Butt & $(-)$ & $(-)$ & Syringe Centrix & Copal Varnish, vaseline, Soflex ${ }^{\circledR}$ discs\# \\
\hline Amalgam ${ }^{a}$ & Butt & $(-)$ & $(-)$ & Condensate & Multi-bladed bur, Abrasive rubber* \\
\hline Z-100 & Bevel & $(+)$ & Scotchbond MP\# & \multirow{3}{*}{$\begin{array}{l}\text { Increments } \\
\text { light-cured for } \\
40 \text { s each one }\end{array}$} & \multirow{3}{*}{$\begin{array}{l}\text { Finishing bur* } \\
\text { and Soflex }{ }^{\circledR} \text { discs\# }\end{array}$} \\
\hline Ariston pHc & Butt & $(-)$ & Liner (Vivadent) & & \\
\hline Heliomolar & Bevel & $(+)$ & Scotchbond MP\# & & \\
\hline
\end{tabular}

${ }^{a}$ additional retention and a copal varnish layer were applied prior to the restoration; ${ }^{b}(+)$ used/done; (-) not used/not done; ${ }^{*} K G$ Sorensen; \#3M. 
al. ${ }^{5}$ (1990), that was modified in the incubation period, which was enlarged, and in the culture medium, which was changed. The microorganism used was Streptococcus mutans (ATCC 25175), which was incubated in TSB (Difco-Becton, Dickinson and Company - Sparks, MD, USA) with $5 \%$ sucrose $\left(37^{\circ} \mathrm{C}\right.$ for $\left.24 \mathrm{~h}\right)$ in order to induce bacterial growth. The bacteria were plated in a solid culture medium (TSA, Difco-Becton, Dickinson and Company Sparks, MD, USA) to obtain isolated colonies and incubated again $\left(37^{\circ} \mathrm{C}\right.$ for $\left.24 \mathrm{~h}\right)$. Then, the grown colonies were transferred to tubes containing TSB and $5 \%$ sucrose, starting a preconditioning of the microorganism with sucrose for 6 days. This way, the tube containing the inoculum broth was obtained with approximately $1.84 \times 10^{6}$ colony-forming units $(\mathrm{CFU}) / \mathrm{ml}$. Each tooth was immersed in a tube containing TSB $+5 \%$ sucrose and $200 \mu$ of the inoculum broth. The teeth were maintained in this bacterial system for 30 days, being transferred to a fresh tube every $48 \mathrm{~h}$. During the incubation period, tests were performed to check for contaminants. After 30 days, the teeth were removed from the bacterial system and the steel wires were removed.

The teeth were sectioned with double face diamond discs (Discoflex, KG Sorensen, Barueri, SP, Brazil) to separate the buccal from the lingual surfaces. Each aspect was embedded in epoxy resin (Resigel - Redlease ${ }^{\circledR}$, Varzea Paulista, SP, Brazil), and sectioned with a Labcut Machine ${ }^{\circledast}$ (Extec 1010, Excel Technologies Inc., Enfield, CT, USA) in a buccolingual direction, resulting in specimens with $500 \mu \mathrm{m}$ in thickness. Two of these sections were randomly chosen and ground by hand to a thickness around $100 \mu \mathrm{m}$ using sandpaper numbers 150, 220, 400, and 600 (Norton Abrasivos Brasil - Igarassu, PE, Brazil).

Each chosen section was examined under a light microscope (Citoval 2 with CarlZeiss lens - Laboral 4, Zeiss, Thornwood, NY, USA) coupled to a software (DIRACOM 3, Imagelab 2000, São Paulo, SP Brazil) to capture and process the images (LIDO, University of São Paulo) in order to do the following measurements (variables) in the occlusal and cervical outer lesion: extension (E) - from one lesion margin up to the opposite margin; depth (D) - at the deepest point of the lesion; inhibition area (IA) - distance between lesion and restoration margin. So, four positions of each tooth (buccal/occlusal, lingual/occlusal, buccal/cervical and lingual/cervical) were analyzed following those criteria due to anatomical and histological differences of the crowns, and the data were subjected to statistical analyses. For each variable, Analysis of Variance was used to test the equality of means between the groups. Because of the dependence of the four measurements in each tooth, Component Variance Models were also used in the analysis. ${ }^{13}$

The same sections were also examined using polarized light microscopy, embedding in water and quinoline, in order to visualize the lesions.

\section{Results}

The enamel surface subjected to the cariogenic challenge presented a white and opaque appearance. Microscopically, outer lesions with or without caries inhibition zones were observed (Figure 1), whereas wall lesions were not seen in the cavities in any of the specimens. Polarized-light examination showed an intact surface layer above the lesion body, which had a rectangular shape and positive and negative birefringence when embedded in water and quinoline, respectively. When quinoline was used, we could observe, in some sections, the dark zone and the translucent zone under it.

The samples' means were grouped when the values for the material groups and for the dental sites were similar. Tables 2, 3 and 4 show the statistically different groups and sites.

Regarding lesion extension (E) (Table 2), it was shown that the GIC had the statistically smallest mean values, followed by amalgam and Ariston $\mathrm{pHc}$, which were statistically similar to each other $(\mathrm{p}>0.05)$. For the four dental positions, the comparison of $E$ rejected the equality of the means within each group $(\mathrm{p}=0.0109)$, and by using contrasts, the equality of means was detected for the occlusal $(\mathrm{p}=0.1684)$ and cervical sites $(\mathrm{p}=0.0662)$. Similar results were obtained for the depth of lesions (D) (Table 3). However, for this variable, contrast analysis indicated equality of means for the cervical sites $(p=0.3865)$, but not for the occlusal sites 

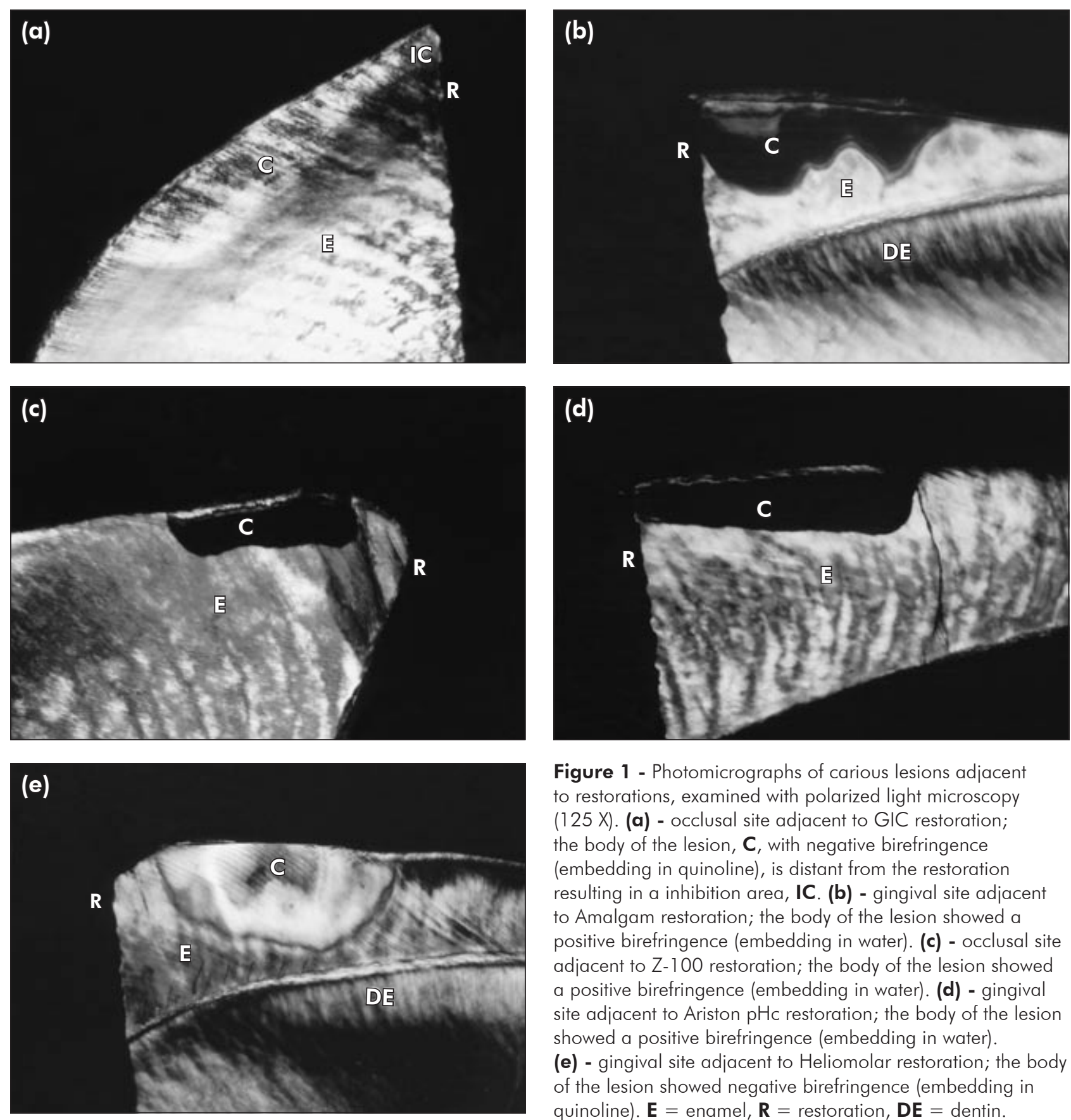

Figure 1 - Photomicrographs of carious lesions adjacent to restorations, examined with polarized light microscopy (125 X). (a) - occlusal site adjacent to GIC restoration; the body of the lesion, $\mathbf{C}$, with negative birefringence (embedding in quinoline), is distant from the restoration resulting in a inhibition area, IC. (b) - gingival site adjacent to Amalgam restoration; the body of the lesion showed a positive birefringence (embedding in water). (c) - occlusal site adjacent to Z-100 restoration; the body of the lesion showed a positive birefringence (embedding in water). (d) - gingival site adjacent to Ariston $\mathrm{pHc}$ restoration; the body of the lesion showed a positive birefringence (embedding in water).

(e) - gingival site adjacent to Heliomolar restoration; the body of the lesion showed negative birefringence (embedding in quinoline). $\mathbf{E}=$ enamel, $\mathbf{R}=$ restoration, $\mathbf{D E}=$ dentin.

$(\mathrm{p}=0.0275)$. Tables 2 and 3 show the estimates and the confidence intervals for the means of these variables.

The GIC group showed the highest number and size $(0.05 \mathrm{~mm} \pm 0.01)$ of inhibition areas (IA), statistically different from those of the other groups. Differences among these other groups were not statistically detected $(\mathrm{p}>0.05)$. The equality of means

was observed for all dental positions $(\mathrm{p}=0.1693)$. These data are shown in Table 4.

\section{Discussion}

The bacterial method for in vitro caries formation has been used because it allows not only the demineralization of dental tissue, but it also favors the investigation of different anticariogenic proper- 
Table 2 - Means, standard deviation (SD) and confidence intervals (CI) of lesion extension (mm).

\begin{tabular}{l|c|c|c|c|c|c}
\hline \multirow{2}{*}{ Restorative Material* } & \multicolumn{3}{|c|}{ Occlusal sites* } & \multicolumn{3}{c}{ Cervical sites* } \\
\cline { 2 - 7 } & Mean & SD & Cl & Mean & SD & Cl \\
\hline Ketac Fil & 1.52 & 0.07 & $(1.38,1.66)$ & 1.37 & 0.07 & $(1.23,1.51)$ \\
\hline Amalgam and Ariston pHc & 1.63 & 0.05 & $(1.53,1.73)$ & 1.48 & 0.05 & $(1.38,1.58)$ \\
\hline Z-100 and Heliomolar & 1.81 & 0.05 & $(1.71,1.91)$ & 1.66 & 0.05 & $(1.56,1.76)$ \\
\hline
\end{tabular}

*Statistically similar groups and sites are grouped. Confidence coefficients are 0.95 .

Table 3 - Means, standard deviation (SD) and confidence intervals (Cl) of lesion depth (mm).

\begin{tabular}{|c|c|c|c|c|c|c|c|c|c|}
\hline \multirow{3}{*}{ Restorative Material* } & \multicolumn{6}{|c|}{ Occlusal Sites } & \multirow{2}{*}{\multicolumn{3}{|c|}{$\begin{array}{c}\text { Cervical sites* } \\
\text { Buccal and Lingual }\end{array}$}} \\
\hline & \multicolumn{3}{|c|}{ Buccal } & \multicolumn{3}{|c|}{ Lingual } & & & \\
\hline & Mean & SD & $\mathrm{Cl}$ & Mean & SD & $\mathrm{Cl}$ & Mean & SD & $\mathrm{Cl}$ \\
\hline Ketac Fill & 0.29 & 0.02 & $(0.25,0.33)$ & 0.32 & 0.02 & $(0.28,0.36)$ & 0.40 & 0.02 & $(0.36,0.44)$ \\
\hline Amalgam and Ariston $\mathrm{pHc}$ & 0.41 & 0.02 & $(0.37,0.45)$ & 0.44 & 0.02 & $(0.40,0.48)$ & 0.52 & 0.02 & $(0.48,0.56)$ \\
\hline Z-100 and Heliomolar & 0.49 & 0.02 & $(0.45,0.53)$ & 0.52 & 0.02 & $(0.48,0.56)$ & 0.60 & 0.02 & $(0.56,0.64)$ \\
\hline
\end{tabular}

*Statistically similar groups and sites are grouped. Confidence coefficients are 0.95 .

Table 4 - Means, standard deviation (SD) and confidence intervals $(\mathrm{Cl})$ of inhibition area $(\mathrm{mm})$.

\begin{tabular}{l|c|c|c}
\hline \multirow{2}{*}{ Restorative Material* } & \multicolumn{3}{|c}{ All dental positions* } \\
\cline { 2 - 4 } & Mean & SD & $C l$ \\
\hline Ketac Fil & 0.05 & 0.01 & $(0.03,0.07)$ \\
\hline $\begin{array}{l}\text { Ariston pHc, Amalgam, } \\
\text { Z-100 and Heliomolar }\end{array}$ & 0.01 & 0.00 & $(0.00,0.02)$ \\
\hline
\end{tabular}

*Statistically similar groups and sites are grouped. Confidence coefficients are 0.95 .

ties of restorative materials or microleakage around restorations. Because of that, the bacterial method is considered to reproduce very closely the in vivo conditions. ${ }^{3,5}$

It has been reported that restorative materials can induce a variable amount of bacterial retention, and that is an important parameter in the etiology of secondary caries formation. However, restorative materials can inhibit bacterial growth and favor the remineralization through ion release and, if the material allows a good marginal seal, it can be considered one of the protecting mechanisms against secondary caries. ${ }^{11}$ Good marginal seal also depends on the site of the crown where the cavosurface margin is located. Some sites make the marginal seal more difficult than others due to anatomical landmarks, and this is the reason for the model of statistical analyses adopted in this study considering the four sites of the crown: occlusal and cervical of the buccal and lingual portions of the restorations. These are important factors, especially in the treatment of patients with high caries-risk.

In the current study, the microleakage necessary for the development of wall lesions did not occur, or it was too small, probably due to the restorative techniques and thermocycling method used. All lesions clearly extended straight into the cavity wall at a $90^{\circ}$ angle or curved upward. Probably, a method that induces a gap between the dental wall and the restoration would induce enough microleakage to allow the development of wall lesions. ${ }^{5,19}$

The conditions of our study and the absence of wall lesions allowed us to ignore microleakage events, despite the high complexity of the environment at the tooth-restoration interface where the bacterial media was used for the cariogenic challenge. ${ }^{6}$ We can assume that the different responses observed were promoted by the materials used, as the in vitro restorations were easily accessed and clearly visualized favoring the marginal seal.

Although the possibility of outer lesions of secondary caries is poorly affected by the anticario- 
genic properties of restorative materials, ${ }^{6}$ it has been observed that the depth of these lesions is mainly altered by the concentration of cariostatic agents such as mercury, silver, zinc, copper and fluoride on the dental surface. ${ }^{9}$ Thus, the capacity of restorative materials to release such agents as well as the ability of their incorporation by the adjacent dental structure should be considered in tooth protection against secondary caries. The smallest lesions close to the GIC restorations probably occurred due to the high concentration and release of fluoride from GIC, ${ }^{16}$ and it has been already shown that this situation can decrease significantly $S$. mutans levels in a cariogenic challenge in situ. ${ }^{1}$ Our results are also in agreement with those of other studies. ${ }^{8,9}$

The anticariogenic action of metallic elements released by amalgam restorations can explain the small lesions observed in this group, suggesting lower secondary caries risk and slower progression of a lesion around amalgam restorations than around resin ones. ${ }^{12,20}$ The small lesions also found with Ariston $\mathrm{pHc}$ may be related to the release of calcium, fluoride and hydroxyl and this finding is in agreement with the results of another study ${ }^{10}$ that also showed that Ariston pHc hampers demineralization next to the restoration. In contrast, the Z100 and Heliomolar composite resin groups developed large lesions according to all parameters and positions studied, in agreement with the results of another study that also observed wider outer lesions using composite resin ${ }^{8}$ probably due to the lack of fluoride release and antibacterial properties of the composite resin restorations. ${ }^{17,18}$

Composite resins, even those containing fluoride, do not show any anticariogenic action, ${ }^{7}$ and have no

\section{References}

1. Benelli EM, Serra MC, Rodrigues Jr AL, Cury JA. In situ anticariogenic potential of glass ionomer cement. Caries Res. 1993;27(4):280-4.

2. Burke FIT, Wilson NHF, Cheung SW, Mjor IA. Influence of patient factors on age of restorations - a failure and reasons for their placement and replacement. J Dent. 2001;29(5):31724.

3. Dummer PMH, Edmunds DH, Green RM. Demineralization of human enamel by Streptococcus mutans NCTC 10832 other carious inhibitory substance. ${ }^{12}$ In contrast, it was demonstrated in vitro that resinous materials can favor $S$. mutans grow th ${ }^{4}$ and the deposit of bacterial colonies on the restoration, ${ }^{11,20}$ probably due to its organic constitution. Furthermore, the resinous matrix may prevent the contact of fluoride with water, resulting in a low release of this ion. On the other hand, composite resins adhering to the dental structure through adhesives improve the marginal seal, which probably inhibited wall lesions.

Besides the ability to inhibit caries development, other factors should be evaluated when choosing a restorative material. Adhesion, marginal seal, and the mechanical and aesthetic properties are also relevant characteristics that should be taken into account. Other experimental designs should also be tested to further evaluate microleakage in secondary caries development.

\section{Conclusions}

GIC was the material that statistically promoted the best protection against secondary caries development when used as a restorative material in vitro, followed by amalgam and Ariston pHc. The composite resins used did not seem to promote any protection of the dental structure against secondary outer lesions.

\section{Acknowledgments}

We wish to thank Prof. Moacyr Domingos Novelli for his assistance with the Imagelab software, and Prof. Patricia Gama for her English language revision. This study was Supported by The State of São Paulo Research Foundation (FAPESP, grant $n$. 99/12518-5).

using a sequential batch culture technique. Caries Res. 1982;16(2):193-6.

4. Friedl KH, Schmalz G, Hiller KA. Flüssigklitskulturen zur prüfung der wirkung zahänarztlischer werkstoffe auf des Bakterienwachstun. Dtsch Zahnarzte Z. 1992;47(12):2826-31.

5. Gilmour SM, Edmunds DH, Dummer PM. The production of secondary caries-like lesions on cavity walls and the assessment of microleakage using an in vitro microbial caries system. J Oral Rehabil. 1990;17(6):573-8. 
6. Grossman ES, Matejka JM. Reliability of outer lesion secondary caries as a predictor of wall lesions. Am J Dent. 1999;12(1):31-6.

7. Hara AT, Turssi CP, Serra MC, Nogueira MC. Extent of the cariostatic effect on root dentin provided by fluoride-containing restorative materials. Oper Dent. 2002;27(5):480-7.

8. Hattab FN, Mok NY, Agnew EC. Artificially formed caries like lesions around restorative materials. J Am Dent Assoc. 1989;118(2):193-7.

9. Hsu CYS, Donly KJ, Drake DR, Ewfel JS. Effects of aged fluoride-containing restorative materials on recurrent root caries. J Dent Res. 1998;77(2):418-25.

10. Kielbassa AM, Schulte-Monting J, Garcia-Godoy F, MeyerLueckel H. Initial in situ secondary caries formation: effect of various fluoride-containing restorative materials. Oper Dent. 2003;28(6):765-72.

11. Krasse BG. Prediction and prevention of recurrent caries based on microbiological assays. In: Anusavice KJ. Quality evaluation of dental restorations. Chicago: Quintessence; 1989. p. 199-209.

12. Leinfelder KF. Criteria for clinical evaluation of composite resin restorations. In: Anusavice KJ. Quality evaluation of dental restorations. Chicago: Quintessence; 1989. p. 13949.
13. Lindsey JK. Models for repeated measurement. Oxford: Clarendon; 1993.

14. Mjor I A, Shen C, Eliasson ST, Richter S. Placement and replacement of restorations in general dental practice in Iceland. Oper Dent. 2002;27(2):117-23.

15. Orstavik D. Antibacterial properties of and element release from some dental amalgams. Acta Odontol Scand. 1985;43(4):231-9.

16. Preston AJ, Mair LH, Agalamanyi EA, Higham SM. Fluoride release from aesthetic dental materials. J Oral Rehabil. 1999;26(2):123-9.

17. Sarret DC. Clinical challenges and the relevance of materials testing for posterior composite restorations. Dent Mater. 2005;21(1):9-20.

18. Savarino L, Breschi L, Tedaldi M, Ciapetti G, Tarabusi C, Greco $\mathrm{M}$ et al. Ability of restorative and fluoride releasing materials to prevent marginal dentine demineralization. Biomaterials. 2004;25(6):1011-7.

19. Schiffner U. Inhibition of enamel and root dentin demineralization by Ariston pHc: an artificial mouth study. Am J Dent. 1999;12 Spec No:S10-2.

20. Svanberg M, Mjör IA, Orstavik D. Mutans streptococci in plaque from margins of amalgam, composite, and glass-ionomer restoration. J Dent Res. 1990;69(3):861-4. 